\title{
A STUDY ON CONSUMER SATISFACTION TOWARDS ONLINE PURCHASING IN FLIPKART WITH SPECIAL REFERENCE TO KURICHI IN TIRUNELVELI CITY
}

\author{
Dr. U. Jothimani \\ Assistant Professor, Department of Commerce, \\ Annai Haijra College Women's College \\ Melapalyam, Tirunelveli - 627005 \\ Tamilnadu, India
}

\author{
C. Jeya Gowri \\ Assistant Professor, Department of Commerce \\ Annai Haijra College Women's College, \\ Melapalyam, Tirunelveli - 627005 \\ Tamilnadu, India
}

\begin{abstract}
Consumer behaviors may be defined at the behavior that consumer display in searching for purchasing, evaluating and disposing of products, evaluating and disposing of produces, service and ideas which they expect to satisfy their needs". Thus, the study of consumer behavior is the study of how an individual makes decision to spend their available resources-money, time and effort on consumption related items. However, it may be noted that consumer behavior research today goes far beyond "what, why, how, when, where, and how often" fact of consumer behavior and also consider the use of goods they buy and evaluations after use there may be many repercussions after the consumer make a purchase.

In Tirunelveli all so there are such studies regarding various aspects. In such that way, flipkart.com in Tirunelveli city were found to be providing quality product and services to the consumer satisfaction. This prompted the researcher to select the study regarding the various factors influencing the satisfaction level of the consumer retention and their problems. The study has covered the general profile and the shopping habits of the respondents, along with an enumeration of their opinion on the various dimensions of satisfaction to the service provided.
\end{abstract}

Keyword: Consumer, Consumption, Satisfaction, Shopping.

\section{INTRODUCTION}

Now days, Flipkart become the latest and more trending the online shopping sites. But most of the people don't know about the details of Flipkart. Flipkart is an ECommerce company found in 2007 by Sachi Bansal and Binny Bansal. It is registered in Singapore and it operates in India where it Head Quartered in Bangalore, Karnataka. Flipkart is launched its own product range under the name "DigiFlip" with products including tablets USB and laptop bags. In May 2014, Flipkart received \$10 million from DST global and in July at raised \$1 million led existing investor's tiger Global and South Africa's media group Naspers. Flipkart last fund-raising round in December had checked its valuation at $\$ 12$ billion "Consumer behaviors may be defined at the behavior that consumer display in searching for purchasing, evaluating and disposing of products, evaluating and disposing of produces, service and ideas which they expect to satisfy their needs". Thus the study of consumer behavior is the study of how an individual makes decision to spend their available resources-money, time and effort on consumption related items. However, it may be noted that consumer behavior research today goes far beyond "what, why, how, when, where, and how often" fact of consumer behavior and also consider the use of goods they buy and evaluations after use there may be many repercussions after the consumer make a purchase.

\section{STATEMENT OF PROBLEM}

In this modern era almost every one of us are using internet and smart phones but many are using the internet. To enhance and attract online customer it is very important to know about their behavior and understand what they require and need. Since online shopping is the new medium of shopping with new demands of consumers. All customers have their own desires and demands for products so that it is very crucial for all online retailers to identify and know about their online consumers in flipkart. According to this short period, Flipkart.com attract more customer from Tirunelveli and satisfy them in various way. Company strategy should be high. So it is very much required for any marketer to access the consumer preference so the present study will contribute in this regarding and focuses to know the consumer preference and satisfaction level regarding the Flipkart.com product in Tirunelveli city.

\section{OBJECTIVES OF THE STUDY}

- To assess the demographic profile of customer.

- To analysis the satisfaction levels of the customers of the selected online products. 
- To scrutiny the problems faced by the customer in the online shopping.

\section{RESEARCH DESIGN}

The researcher has been selected on convenience sampling technique and the total number of sample was 60 out of which 50 were selected. The structured interview schedule was used to collect the relevant data. Apart from the necessary tables, chart and like suitable statistical tools are applied for analysis and interpretation.

* Percentage Analysis * Garrett Ranking

ANALYSIS AND INTERPRETATION
GENDER WISE CLASSIFICATION
\begin{tabular}{|c|c|c|c|}
\hline $\begin{array}{c}\text { Serial } \\
\text { No }\end{array}$ & $\begin{array}{c}\text { Sexual } \\
\text { category }\end{array}$ & Respondents & $\mathbf{\%}$ \\
\hline 1 & Male & 28 & 56 \\
\hline 2 & Female & 22 & 44 \\
\hline \multicolumn{2}{|c|}{ Total } & $\mathbf{5 0}$ & $\mathbf{1 0 0}$ \\
\hline
\end{tabular}

AGE WISE CLASSIFICATION

\begin{tabular}{|c|c|c|c|}
\hline $\begin{array}{c}\text { Serial } \\
\text { No` }\end{array}$ & Age & Respondents & \% \\
\hline 1 & $21-30$ & 17 & 34 \\
\hline 2 & $31-40$ & 08 & 18 \\
\hline 3 & $41-50$ & 11 & 22 \\
\hline 4 & $\begin{array}{c}\text { More than } \\
50\end{array}$ & 13 & 26 \\
\hline & Total & $\mathbf{5 0}$ & $\mathbf{1 0 0}$ \\
\hline
\end{tabular}

EDUCATIONAL CRITERION

\begin{tabular}{|c|c|c|c|}
\hline $\begin{array}{c}\text { Serial } \\
\text { No }\end{array}$ & Qualification & Respondents & \% \\
\hline 1 & HSC & 15 & 30 \\
\hline 2 & Degree & 19 & 38 \\
\hline 3 & Diploma & 10 & 20 \\
\hline 4 & Others & 6 & 12 \\
\hline & Total & $\mathbf{5 0}$ & $\mathbf{1 0 0}$ \\
\hline
\end{tabular}

MARTIAL STATUS WISE CLASSIFICATION

\begin{tabular}{|c|c|c|c|}
\hline $\begin{array}{c}\text { Serial } \\
\text { No }\end{array}$ & $\begin{array}{c}\text { Marital } \\
\text { Status }\end{array}$ & Respondents & \% \\
\hline 1 & Unmarried & 26 & 52 \\
\hline 2 & Married & 24 & 48 \\
\hline & Total & $\mathbf{5 0}$ & $\mathbf{1 0 0}$ \\
\hline
\end{tabular}

\section{SIZE OF FAMILY UNIT OF RESPONDENTS}

\begin{tabular}{|c|c|c|c|}
\hline $\begin{array}{c}\text { Serial } \\
\text { No }\end{array}$ & Family Size & Respondents & \% \\
\hline 1 & $\begin{array}{c}\text { Nuclear } \\
\text { family }\end{array}$ & 33 & 66 \\
\hline 2 & Joint family & 17 & 34 \\
\hline
\end{tabular}

\begin{tabular}{|c|c|c|c|}
\hline & Total & 50 & 0 \\
\hline \multicolumn{4}{|c|}{ OCCUPATION WISE CLASSIFICATION } \\
\hline $\begin{array}{c}\text { Serial } \\
\text { No }\end{array}$ & Occupation & Respondents & $\%$ \\
\hline 1 & Student & 12 & 24 \\
\hline 2 & Private & 19 & 38 \\
\hline 3 & Government & 13 & 26 \\
\hline 4 & Business & 6 & 12 \\
\hline & Total & 50 & 100 \\
\hline
\end{tabular}

\section{TIME SPEND ON INTERNET}

\begin{tabular}{|c|c|c|c|}
\hline $\begin{array}{c}\text { Serial } \\
\text { No }\end{array}$ & Particulars & Respondents & \% \\
\hline 1 & Below 1 hour & 07 & 14 \\
\hline 2 & 1 hour & 24 & 48 \\
\hline 3 & $2-3$ hours & 11 & 22 \\
\hline 4 & 3-6 hours & 08 & 16 \\
\hline & Total & $\mathbf{5 0}$ & $\mathbf{1 0 0}$ \\
\hline
\end{tabular}

\section{KNOWLEDGE OF FLIPKART}

\begin{tabular}{|c|c|c|c|}
\hline $\begin{array}{c}\text { Serial } \\
\text { No }\end{array}$ & Particulars & Respondents & \% \\
\hline 1 & Well knowledge & 32 & 64 \\
\hline 2 & Some what & 18 & 36 \\
\hline & Total & $\mathbf{5 0}$ & $\mathbf{1 0 0}$ \\
\hline
\end{tabular}

\section{PERIOD OF ACCESS FLIPKART.COM}

\begin{tabular}{|c|c|c|c|}
\hline $\begin{array}{c}\text { Serial } \\
\text { No }\end{array}$ & Particulars & $\begin{array}{c}\text { Responde } \\
\text { nts }\end{array}$ & \% \\
\hline 1 & Less than 1 year & 9 & 18 \\
\hline 2 & 2 to 3 years & 13 & 26 \\
\hline 3 & 3 to 4 years & 11 & 22 \\
\hline 4 & 4 to 5 years & 5 & 10 \\
\hline 5 & Above 5 years & 12 & 24 \\
\hline & Total & $\mathbf{5 0}$ & $\mathbf{1 0 0}$ \\
\hline
\end{tabular}

THE PRICE OF THE PRODUCT OFFERED

\begin{tabular}{|c|c|c|c|}
\hline $\begin{array}{c}\text { Serial } \\
\text { No }\end{array}$ & Particulars & Respondents & \% \\
\hline 1 & Reasonable & 23 & 26 \\
\hline 2 & High Price & 13 & 46 \\
\hline 3 & $\begin{array}{c}\text { At a } \\
\text { discount }\end{array}$ & 14 & 28 \\
\hline & Total & $\mathbf{5 0}$ & $\mathbf{1 0 0}$ \\
\hline
\end{tabular}

OPINION ABOUT DISPLAY OF PRICE RANGE FOR THE PRODUCT

\begin{tabular}{|c|c|c|c|}
\hline $\begin{array}{c}\text { Serial } \\
\text { No }\end{array}$ & Particulars & Respondents & \% \\
\hline 1 & $\begin{array}{c}\text { Greatly } \\
\text { Satisfy }\end{array}$ & 22 & 44 \\
\hline 2 & Satisfy & 11 & 22 \\
\hline 3 & Unbiased & 06 & 12 \\
\hline
\end{tabular}


Published Online December 2020 in IJEAST (http://www.ijeast.com)

\begin{tabular}{|c|c|c|c|}
\hline 4 & $\begin{array}{c}\text { Highly } \\
\text { Unhappy }\end{array}$ & 02 & 4 \\
\hline 5 & Unhappy & 09 & 18 \\
\hline & Total & $\mathbf{5 0}$ & $\mathbf{1 0 0}$ \\
\hline
\end{tabular}

PURPOSE OF VISIT FLIPKART.COM

\begin{tabular}{|c|c|c|c|}
\hline $\begin{array}{c}\text { Serial } \\
\text { No } \\
\end{array}$ & Particulars & Respondents & $\%$ \\
\hline 1 & Price & 07 & 14 \\
\hline 2 & Variety & 24 & 48 \\
\hline 3 & $\begin{array}{l}\text { Discount and } \\
\text { offer provided }\end{array}$ & 13 & 26 \\
\hline 4 & Others & 6 & 12 \\
\hline & Total & 50 & 100 \\
\hline
\end{tabular}

IMPACT OF PROMOTIONAL ACTIVITIES

\begin{tabular}{|c|c|c|c|}
\hline $\begin{array}{c}\text { Serial } \\
\text { No }\end{array}$ & Particulars & Respondents & \% \\
\hline 1 & $\begin{array}{c}\text { Strongly } \\
\text { Consent }\end{array}$ & 16 & 32 \\
\hline 2 & Consent & 13 & 26 \\
\hline 3 & Unbiased & 8 & 16 \\
\hline 4 & Dissent & 11 & 22 \\
\hline 5 & $\begin{array}{c}\text { Strongly } \\
\text { Dissent }\end{array}$ & 2 & 4 \\
\hline & Total & 50 & 100 \\
\hline
\end{tabular}

\section{AVAILABILITY OF VARIOUS BRANDS}

The following table shows the availability of various brands.

\begin{tabular}{|c|c|c|c|}
\hline $\begin{array}{c}\text { Serial } \\
\text { No }\end{array}$ & Particulars & Respondents & \% \\
\hline 1 & Agree & 36 & 72 \\
\hline 2 & Disagree & 14 & 28 \\
\hline \multicolumn{2}{|c|}{ Total } & $\mathbf{5 0}$ & $\mathbf{1 0 0}$ \\
\hline
\end{tabular}

PROBLEMS IN ONLINE PURCHASING

\begin{tabular}{|c|c|c|c|}
\hline $\begin{array}{c}\text { Serial } \\
\text { No }\end{array}$ & Particulars & Respondents & \% \\
\hline 1 & Yes & 44 & 68 \\
\hline 2 & No & 6 & 32 \\
\hline & Total & $\mathbf{5 0}$ & $\mathbf{1 0 0}$ \\
\hline
\end{tabular}

\begin{tabular}{|c|c|c|c|}
\multicolumn{5}{c}{ KINDS OF PROBLEM FACED } \\
\hline $\begin{array}{c}\text { Serial } \\
\text { No }\end{array}$ & Particulars & Respondents & $\%$ \\
\hline 1 & $\begin{array}{c}\text { Delay in } \\
\text { Delivery }\end{array}$ & 31 & 62 \\
\hline 2 & $\begin{array}{c}\text { Cheap } \\
\text { Quality of } \\
\text { Product }\end{array}$ & 11 & 22 \\
\hline 3 & $\begin{array}{c}\text { Product } \\
\text { Damage }\end{array}$ & 07 & 14 \\
\hline 4 & $\begin{array}{c}\text { Non } \\
\text { Delivery } \\
\text { Total }\end{array}$ & 01 & 2 \\
\hline \multicolumn{3}{|c|}{} \\
\hline
\end{tabular}

OPINION ABOUT GUARANTEE AND WARRANTY

\begin{tabular}{|c|c|c|c|}
\hline $\begin{array}{c}\text { Serial } \\
\text { No }\end{array}$ & Particulars & Respondents & \% \\
\hline 1 & First-rate & 14 & 28 \\
\hline 2 & Fine & 22 & 44 \\
\hline 3 & Fair & 11 & 22 \\
\hline 4 & underprivileged & 3 & 6 \\
\hline \multicolumn{3}{|c}{} \\
\hline
\end{tabular}

SAFETY ABOUT PERSONAL INFORMATION

\begin{tabular}{|c|c|c|c|}
\hline $\begin{array}{c}\text { Serial } \\
\text { No }\end{array}$ & Particulars & Respondents & \% \\
\hline 1 & $\begin{array}{c}\text { Extremely } \\
\text { Confident }\end{array}$ & 27 & 54 \\
\hline 2 & $\begin{array}{c}\text { Quite } \\
\text { Confident }\end{array}$ & 09 & 18 \\
\hline 3 & $\begin{array}{c}\text { Moderately } \\
\text { Confident }\end{array}$ & 11 & 22 \\
\hline 4 & $\begin{array}{c}\text { Slightly } \\
\text { Confident }\end{array}$ & 02 & 4 \\
\hline 5 & $\begin{array}{c}\text { Not at all } \\
\text { Confident }\end{array}$ & 01 & 2 \\
\hline & Total & $\mathbf{5 0}$ & $\mathbf{1 0 0}$ \\
\hline
\end{tabular}

DELIVERY/ SHIPMENT CHARGES

\begin{tabular}{|c|c|c|c|}
\hline $\begin{array}{c}\text { Serial } \\
\text { No }\end{array}$ & Particulars & Respondents & \% \\
\hline 1 & No Charges & 2 & 4 \\
\hline 2 & $\begin{array}{c}\text { High } \\
\text { Charges }\end{array}$ & 11 & 22 \\
\hline 3 & $\begin{array}{c}\text { Moderate } \\
\text { Charges }\end{array}$ & 3 & 6 \\
\hline 4 & $\begin{array}{c}\text { Low } \\
\text { Charges }\end{array}$ & 34 & 68 \\
\hline & Total & $\mathbf{5 0}$ & $\mathbf{1 0 0}$ \\
\hline
\end{tabular}

CONVENIENT IN ONLINE SHOPPING

The following table shows the convenient in online shopping.

\begin{tabular}{|c|c|c|c|}
\hline $\begin{array}{c}\text { Serial } \\
\text { No }\end{array}$ & Particulars & Respondents & \% \\
\hline 1 & Yes & 22 & 44 \\
\hline 2 & No & 28 & 56 \\
\hline & Total & $\mathbf{5 0}$ & $\mathbf{1 0 0}$ \\
\hline
\end{tabular}

EASY PAYMENT METHOD

\begin{tabular}{|c|c|c|c|}
\hline $\begin{array}{c}\text { Serial } \\
\text { No }\end{array}$ & Particulars & Respondents & \% \\
\hline 1 & Yes & 37 & 74 \\
\hline 2 & No & 13 & 26 \\
\hline & Total & $\mathbf{5 0}$ & $\mathbf{1 0 0}$ \\
\hline
\end{tabular}

OVERALL SATISFACTION

\begin{tabular}{|c|c|c|c|}
\hline $\begin{array}{c}\text { Serial } \\
\text { No }\end{array}$ & Particulars & Respondents & \% \\
\hline 1 & Strongly Consent & 17 & 34 \\
\hline
\end{tabular}




\begin{tabular}{|c|c|c|c|}
\hline 2 & Consent & 12 & 24 \\
\hline 3 & Unbiased & 7 & 14 \\
\hline 4 & Dissent & 8 & 16 \\
\hline 5 & Strongly Dissent & 6 & 12 \\
\hline & Total & $\mathbf{5 0}$ & $\mathbf{1 0 0}$ \\
\hline
\end{tabular}

From the above table out of 50 respondents. 34 percentage of respondents are highly satisfied, 24 percentage of respondents are satisfied, 14 percentage of respondents are

PAYMENT SECURITY LEVEL

\begin{tabular}{|c|c|c|c|}
\hline $\begin{array}{c}\text { Serial } \\
\text { No }\end{array}$ & Particulars & Respondents & \% \\
\hline 1 & Outstanding & 16 & 32 \\
\hline 2 & Very Great & 12 & 24 \\
\hline 3 & Great & 9 & 18 \\
\hline 4 & Reasonable & 6 & 12 \\
\hline 5 & Poor & 7 & 14 \\
\hline & Total & $\mathbf{5 0}$ & $\mathbf{1 0 0}$ \\
\hline
\end{tabular}

GARRET VALUE Ranking of factor influence which increased in you affect become a flipkart.com.

\begin{tabular}{|c|c|c|c|c|c|c|c|c|}
\hline SI & Factors & Factor & \multicolumn{5}{|c|}{ RANKING NO. } & Tot \\
\cline { 4 - 8 } & & no & $\mathbf{1}$ & $\mathbf{2}$ & $\mathbf{3}$ & $\mathbf{4}$ & $\mathbf{5}$ & al \\
\hline 1 & $\begin{array}{c}\text { Fast } \\
\text { delivery }\end{array}$ & F1 & 9 & 13 & 21 & 2 & 5 & 50 \\
\hline 2 & Availability & F2 & 12 & 7 & 19 & 8 & 4 & 50 \\
\hline 3 & $\begin{array}{c}\text { After sales } \\
\text { and services }\end{array}$ & F3 & 14 & 9 & 4 & 12 & 11 & 50 \\
\hline 4 & $\begin{array}{c}\text { Easy } \\
\text { payment } \\
\text { option }\end{array}$ & F4 & 16 & 6 & 7 & 12 & 9 & 50 \\
\hline 5 & $\begin{array}{c}\text { Portal } \\
\text { feature }\end{array}$ & F5 & 21 & 8 & 6 & 11 & 4 & 50 \\
\hline
\end{tabular}

CALCULATE AVERAGE SCORE AND RANK

\begin{tabular}{|c|c|c|c|c|}
\hline S. No & Factor & Total & Average & Rank \\
\hline 1 & F1 & 2707 & 54.14 & 2 \\
\hline 2 & F2 & 2686 & 53.72 & 3 \\
\hline 3 & F3 & 2534 & 50.68 & 5 \\
\hline 4 & F4 & 2606 & 52.12 & 4 \\
\hline 5 & F5 & 2893 & 57.86 & 1 \\
\hline
\end{tabular}

It is observed from that table 4.27 that "Portal feature" has been ranked as the first position influence the beneficiaries to select the particular flipkart.com, " Fast Delivery" has been ranked as second position, "Availability" has been ranked as third position, "Easy payment" has been raked as fourth position, "After sales and services" has been ranked as fifth position.

\section{FINDING}

- Majority of the respondents (56\%)were male.

- Majority of the respondents (34\%) between the age group of 21-30.

- Majority of the respondents (38\%) educational qualification were degree.

- Majority of the respondents (52\%)were unmarried
- Majority of the respondents (66\%) family were nuclear family.

- Majority of the respondents (44\%) were students.

- Majority of the respondent (48\%) Time spend on internet for 1 hour.

- Majority of the respondents (64\%) were well knowledge about flipkart.

- Majority of the respondents (26\%) using flipkart.com for 2-3 years.

- Majority of the respondents (46\%) opinion that price of the product offers were reasonable.

- Majority of the respondents (44\%) are highly satisfied with display of price range of the product.

- Majority of the respondents (48\%) are visiting flipkart.com for "variety of product".

- Majority of the respondents (32\%) are strongly agree the impact of promotional activities.

- Majority of the respondents (54\%) are prefer to buy "electronic products".

- Majority of the respondents (72\%) are "Agree" with availability of various brands.

- Majority of the respondents (88\%) say "Yes" problems in online purchasing.

- Majority of the respondents (88\%) says "Yes" to problems in online purchasing.

- Majority of the respondents(44\%) opinion "Good" to guarantee and warranty

- Majority of the respondents (54\%) are extremely confident with safety about personal information.

- Majority of the respondents (68\%) says delivery/shipment charges are "low ".

- Majority of the respondents (56\%) are undergo with "inconvenient" about online shopping.

- Majority of the respondents (74\%) feel easy on payment method

- Majority of the respondents (34\%) are "highly satisfied" with overall satisfaction.

- Majority of the respondents (32\%) says that the payment security level is "excellent".

\section{SUGGESTION}

- $\quad$ Therefore they needs to get aggressive providing better services which can be fulfilled by reducing the delivery time, selling second hand products which will increase consumers' affordability much more and enhance penetration into the market.

- They can even have their retail stores which can give an access to consumer to feel and analyze the product, which will help them win the consumer faith be very focused on consumer and build Flipkart experiences for the consumer satisfaction. 


\section{International Journal of Engineering Applied Sciences and Technology, 2020 \\ Vol. 5, Issue 8, ISSN No. 2455-2143, Pages 153-157 \\ Published Online December 2020 in IJEAST (http://www.ijeast.com)}

- $\quad$ Only educated people are more aware of online shopping so focus should made on people who are not aware of online purchasing.

- To provided better security against malpractices.

- To reduce delivery charges and implement more offer to attract new customer.

- Flipkart should try to reduce the cost and introduce many cheap plans to make it affordable to those who cannot afford, which will in turn help them to increase their customer.

- They can provide more information about the product and services availability which will improve the knowledge of the customers help them shop easily.

- Convenience of shopping can be developed by bringing in user friendly methods of making online purchasing easily.

\section{CONCLUSION}

In the basis of the present study conclude that the online consumer satisfaction. This research explicitly indicates that flipkart online marketer should give were importance on price factor and after sale factor in this competitive world, online marketer should have to offer new scheme day to day attract that the new customers. Online shopping becoming more popular day to day with the increase in the stage of world wide web known as www.understanding customer's need for online selling has become challenge for marketer. In conclusion having access to online shopping has truly revolutionized and influenced our society as a hole. This use of technology has open new doors and opportunities that enable for a more convenient life style today. Variety, Quick service and reduced price were three significant ways a which online shopping led to the possibilities of fraud and privacy conflict. Through privacy and security policies, website designer doing. By doing so, society a will continue to depend upon online shopping, which will allow it to remind a tremendous success in future.

\section{Journals}

\section{REFERENCE}

1. S. Mohanapriya D. Anusuya, (2014), "A Study on Customer Preferences and Satisfaction towards Selected Online Websites with Special Reference to Coimbatore City," Paripex-Indian Journal of Research, Vol. 3, Issue 11, November.

2. Sanjeev Kumar and Savita Maan (2014), Status and Scope of Online Shopping: An Interactive Analysis through Literature Review International Journal of Advanced Research in Computer Science and Management Studies, Vol. 2, Issue 12, December.

3. Prashant Sigh (2014), Consumer's buying behavior towards online shopping national monthly referred journal of research in commerce and management.

4. Wang, C L, Ye, L R Zhang Y and Nguyen D.D, (2005), "Subscription to fee-based online services: What makes consumer pay for online content?" Journal of Electronic Commerce Research, vol. 6.

5.Persson,c (2001)- strategies for enhancing consumer interaction in electronic retailing.

6. Kim, D., Yang,Z., Jun,m. (2003)- Consumer perception of omline retailing services quality and their satisfaction.

7. Aragchi, s (2007)- Services quality, customer satisfaction, customer experience and behavioral intention in Iranian retail store.

8. Delafrooz, N., paim, I., Haron,S., sidin, S., khatibi, A. (2009)- Factor affecting students' attitude toward online shopping.

9. Gopalan, Rangnatham, (2014)- India retailtrends, let's simplify, Tata Business suppliers services limited.

10. Persson,C (2001) strategies for enhancing consumer interaction in electronic retailing.

11. Kim, D., Yang,Z., Jun,M.(2003)- Customers perception of online retailing service quality and their satisfaction.

12. Aragchi, S (2007)- Services quality, customer satisfaction, customer experience and behavioral intention in Iranian retail store.

13. Delafrooz, N., paim, I ., Haron,S. , sidin, S., khatibi, A. (2009) - Factors affecting students' attitude toward online shopping.

14. Gopalan, Rangnatham, (2014)- India retailtrends, let' ssimplify, Tata Businessuppliers services limited.

\section{WEBSITES}

- http://en.wikipedia.org

- www.google.com

- http://www.flipkartcareers.com/

- $\quad$ http://www.slideshare.net

- http://www.scribd.com

- http://www.letsintern.comlemployerpagelinternships-at-Flipkart.com 